\title{
ANALYSIS OF RELATIONSHIP BETWEEN BASIC COMPOSITION, PH, AND PHYSICAL PROPERTIES OF SELECTED BOVINE MUSCLES
}

\author{
JAROSŁAW WYRWISZ, ANDRZEJ PÓŁTORAK, MAGDALENA ZALEWSKA, \\ ROBERT ZAREMBA, AND AGNIESZKA WIERZBICKA \\ Department of Functional Food and Commodities, \\ Faculty of Human Nutrition and Consumer Sciences, \\ Warsaw University of Life Sciences-SGGW, 02-776 Warsaw, Poland \\ jaroslaw_wyrwisz@sggw.pl
}

Received: January 18, 2012

Accepted: August 30, 2012

\begin{abstract}
The aim of this study was to analyse the correlation between basic meat composition (water, protein, fat, and connective tissue contents), $\mathrm{pH}$ value, and physical parameters (texture and colour, drip loss) of selected beef muscles. Five different muscles (LTH, SEM, SET, PSM, TRI) from 20 carcasses were examined. Measurements of the basic meat composition were conducted using a near infrared spectrometry method, colour parameters in $\mathrm{L}^{*} \mathrm{a}^{*} \mathrm{~b}$ system, and texture parameters. Drip loss correlated strongly negatively with the $\mathrm{pH}$ value. Depending on the muscle type, the correlation ranged $-0.601 \leq \mathrm{r} \leq-0.282$, whereas drip loss correlated moderately positively with connective tissue content. The most significant positive correlation $(\mathrm{r} \approx 0.67)$ between hardness, tenderness, and fat content was noted in the SEM. Colour parameters strongly depended on $\mathrm{pH}$ values $\left(-0.831 \leq \mathrm{r}_{\mathrm{L}^{*} \leq-} \leq 0.338\right.$; $0.828 \leq \mathrm{r}_{\mathrm{a}^{*}} \leq-0.542 ;-0.912 \leq \mathrm{r}_{\left.\mathrm{b}^{*} \leq-0.719\right)}$ and to a lesser extent on the content of connective tissue.
\end{abstract}

Key words: beef, $\mathrm{pH}$, basic composition, tenderness, drip loss.

The most important physical characteristics determining bovine meat quality are colour, texture (tenderness), and water holding capacity (WHC) (13, 30). Beef quality is influenced by many factors including: species (Bos taurus vs Bos indicus), breed, sex, age, and type of muscle. Anatomic characteristics are also affected by the husbandry systems including type of feeding and pre-slaughter transportation, as well as post-mortem factors (conditions during slaughter, chilling of carcasses, and their aging) $(23,18)$.

Tenderness and other meat texture parameters are directly associated with the structure of myofibrillar proteins, content of connective tissue, and their interaction. All muscle fibres are built from myofibrils, which contain myosin and actin filaments. The structural integrity of myofibrills changes during maturation, causing improvement of meat tenderness. Hardness of meat is caused by e.g. the shortening of sarcomeres by the rapid cooling of the muscles while they are still in the process of rigor-mortis ("cold shortening") $(33,24)$.

Another factor, which determines the tenderness is the amount of intramuscular fat (IMF) (7, 31). This fat has a more delicate structure than muscle tissue, therefore a high content of intramuscular fat (marbling) increases meat tenderness (34). Moreover, intramuscular fat causes an increase in juiciness and improves the flavour (17).
Physical properties, in particular texture, are dependent on the rate of glycolysis, decrease in temperature after slaughter, and ultimate $\mathrm{pH}$ value of muscles, which is in a range between 5.4 and 7.2 (14). However, the relationship between $\mathrm{pH}$ and tenderness is controversial. Some authors have shown a linear relationship between these two parameters; however, the majority of others suggest that there is a nonlinear dependence of meat hardness within the limits of $\mathrm{pH}$ in the range of 5.8-6.3. This may be due to different proteolytic activity leading to improved tenderness during aging (10). An increase in meat tenderness when $\mathrm{pH}$ increases from 6 to 7 is associated with a higher activity of calpain enzyme, which reaches its maximum activity at neutral $\mathrm{pH}(9)$.

Meat colour is one of the most important visual features. An appropriate proportion and distribution of oxymyoglobin and methmyoglobin is the main determinant of an acceptable colour of fresh meat. The bright red colour of meat occurs due to the oxygenation of myoglobin during exposure to a mixture of gases, which contains oxygen $(6,11)$. Post slaughter glycolysis lowers $\mathrm{pH}$ causing the development of a brighter colour and wetter surface. At high meat $\mathrm{pH}$ values, the physical state of proteins is above their isoelectric point. This causes proteins to absorb water in muscles and therefore the muscles fibres are more tightly packed. A negative 
trait of meat is the dark colour, formed due to its reduced ability to light scattering on the surface, which is called DFD (dark, firm, dry). This was not reported at a lower meat $\mathrm{pH}(1)$.

Evaluation of beef meat texture properties can be measured by objective methods, using extensive instrumental and sensory tests by an expert panel, or by subjective methods - consumer panels (5). Objective methods include the measurement of shear forces, penetration, compression, or torsional force $(29,16)$.

The aim of this study was to analyse the relationship between basic composition (water, protein, fat, and connective tissue content), $\mathrm{pH}$ value, and physical properties (the texture parameters, colour, drip loss) of selected bovine muscles.

\section{Material and Methods}

Sample origin. Five muscles from 20 carcasses were collected from a local slaughterhouse. The slaughtered animals were between 20 and 24 months of age. Carcass weights ranged from 270 to $310 \mathrm{~kg}$, and were grade as being in the $\mathrm{R}$ conformation class with $1+$ and 2- fat cover degree (according to the EUROP classification system). After rigor mortis $\left(48 \mathrm{~h}, 2 \pm 1^{\circ} \mathrm{C}\right)$, the following muscles were separated from the carcasses: M. longissimus thoracis et lumborum - LTH, M. semimembranosus - SEM, M. semitendinosus - SET, $M$. psoas major - PSM and M. triceps branchii - TRI. Then, these muscles were vacuum packed in highbarrier bags and stored at $2 \pm 1{ }^{\circ} \mathrm{C}$ for $5 \mathrm{~d}$. After aging ( 7 $\mathrm{d})$, the muscles were frozen within $2 \mathrm{~h}$ using Küppersbusch blast-freezer and stored at $-18^{\circ} \mathrm{C}$ until later analysis. Thawing of samples was conducted at 2 $\pm 1{ }^{\circ} \mathrm{C}$ for $24 \mathrm{~h}$. After the thawing process, the muscles were removed from their packages and $2.54 \mathrm{~cm}$ thick steaks were sliced.

Drip loss determination. Muscle weight loss during 7-d aging was determined on the basis of the difference in weight before storage $\left(\mathrm{M}_{0}\right)$ and after storage $\left(\mathrm{M}_{1}\right)$ (allowing for the weight of package). Each measurement was performed in five replications, taking the mean value as the assay result. Drip loss $\left(\mathrm{D}_{\mathrm{L}}\right)$ was calculated using the equation (1):

$$
\mathrm{D}_{\mathrm{L}}=\frac{\left(\mathrm{M}_{0}-\mathrm{M}_{1}\right)}{\mathrm{M}_{0}} \cdot 100 \%
$$

where $M_{0}$ - weight before storage, $M_{1}$ - weight after storage.

pH value evaluation. $\mathrm{pH}$ value of the muscles was measured according to the PN-ISO 2917:2001/Ap1:2002 standard. pH-metric results were obtained using a Testo 205 series $\mathrm{pH}$-meter equipped with a glass electrode, which was placed directly into the samples (2 $\mathrm{cm}$ deep into the steaks). Each measurement was performed in five replications, taking the mean value as the assay result. The temperature of samples during measurements was $2 \pm 1{ }^{\circ} \mathrm{C}$.

Instrumental colour measurement in $L * a * b *$ system. Instrumental colour analysis of beef was determined using a Minolta CR-400 chromo meter calibrated against a white plate $\left(\mathrm{L}^{*}=98.45, \mathrm{a}^{*}=-0.10\right.$, $\left.\mathrm{b}^{*}=-0.13\right)$, using an $8 \mathrm{~mm}$ aperture, Illuminate D65 $(6500 \mathrm{~K}$ colour temperature) at a standard observation of $2^{\circ}$. $\mathrm{L}^{*}$ (lightness ranged from 0 to $100 \%$ ), a* (colour axis ranged from greenness $\left(-\mathrm{a}^{*}\right)$ to redness $\left.\left(+\mathrm{a}^{*}\right)\right)$ and $b^{*}$ (colour axis ranged from blueness $\left(-b^{*}\right)$ to yellowness $\left.\left(+b^{*}\right)\right)$. Measurements of the sample were taken from five locations including every quarter and the centre surfaces. Data was collected after a $30 \mathrm{~min}$ blooming period under refrigerated conditions.

Spectrophotometric quantification of basic meat composition. Beef composition (water, fat, protein and connective tissue content $(22,27)$ ) was determined using a near-infrared spectrometer NIRFlex N-500 (Büchi). Measurements were conducted using a NIRFlex Solids module of spectral range $12,500-400 \mathrm{~cm}^{-1}$ in reflectant mode. Meat portions of $100 \mathrm{~g}$ were homogenised and placed on a Petri dish covering the surface with a $0.5 \mathrm{~cm}$ layer. Three measurements of each sample were conducted at a 32 scanning rate.

Warner-Bretzler shear force determination. Instrumental measurement of hardness $(\mathrm{N})$, tenderness $(\mathrm{N})$, and shear energy $(\mathrm{J})$ was conducted using a universal testing machine Instron 5965 with a WarnerBratzler shear attachment consisting of a V-notch blade. Six cores $(1.27 \mathrm{~cm}$ in diameter and $2.5 \pm 0.2 \mathrm{~cm}$ in length) were obtained from each steak parallel to the muscle fibre's orientation. A $500 \mathrm{~N}$ load cell was used and the crosshead speed was set at $200 \mathrm{~mm} / \mathrm{min}$.

Statistical analysis. Data was analysed using StatSoft's Statistica 9.0. Verification of significance of investigated parameters for each muscle type (LSD Fisher test) was performed with the significance level set at $\mathrm{P} \leq 0.05$. Correlation between basic composition of meat, $\mathrm{pH}$ value, and obtained physical parameters was determined using Pearson's linear correlation, and their significances were set at $\mathrm{P} \leq 0.05, \mathrm{P} \leq 0.01$, and $\mathrm{P} \leq 0.001$.

\section{Results and Discussion}

Analysis of differences in the basic composition, pH values, and selected physical properties depending on the type of muscle. Table 1 presents average values of discriminant of the basic meat composition (water, fat, protein, connective tissue content) and the $\mathrm{pH}$ values of the five different beef muscles.

The $\mathrm{pH}$ values recorded reached a similar level $(\mathrm{P}>0.05)$ and ranged between 5.62 and 5.78 indicating no meat defect DFD (dark, firm, dry) (8). The water content ranged between 74.5 and $75.7 \%$. Statistical analysis carried by LSD Fisher test indicated statistically significant differences between water content in LTH and PSM and TRI, SEM, and SET $(\mathrm{P} \leq 0.01)$. Similar results were also obtained by Jeremiah et al. (12) and Li et al. (18), who reported diverse water content in different beef muscles. 
Table 1

Mean \pm standard deviation of the basic meat composition and $\mathrm{pH}$ of beef muscles

\begin{tabular}{llllll}
\hline & $\begin{array}{l}\text { LTH } \\
(\mathrm{n}=20)\end{array}$ & $\begin{array}{l}\text { TRI } \\
(\mathrm{n}=20)\end{array}$ & $\begin{array}{l}\text { SEM } \\
(\mathrm{n}=20)\end{array}$ & $\begin{array}{l}\text { SET } \\
(\mathrm{n}=20)\end{array}$ & $\begin{array}{l}\text { PSM } \\
(\mathrm{n}=20)\end{array}$ \\
\hline Water $(\%)$ & $74.64^{\mathrm{Aa}} \pm 1.83$ & $75.72^{\mathrm{Bb}} \pm 0.99$ & $75.50^{\mathrm{ABb}} \pm 0.97$ & $75.46^{\mathrm{ABb}} \pm 1.08$ & $74.51^{\mathrm{Aa}} \pm 1.31$ \\
\hline Fat $(\%)$ & $2.17^{\mathrm{Bb}} \pm 1.49$ & $1.62^{\mathrm{ABa}} \pm 0.75$ & $1.34^{\mathrm{Aa}} \pm 0.56$ & $1.53^{\mathrm{ABa}} \pm 0.76$ & $1.09^{\mathrm{Aa}} \pm 0.19$ \\
\hline Protein $(\%)$ & $22.47^{\mathrm{Bb}} \pm 0.44$ & $21.90^{\mathrm{Aa}} \pm 0.47$ & $22.62^{\mathrm{Bb}} \pm 0.47$ & $22.39^{\mathrm{Bb}} \pm 0.60$ & $21.80^{\mathrm{Aa}} \pm 0.44$ \\
\hline Connective tissue $(\%)$ & $1.43^{\mathrm{BCb}} \pm 0.35$ & $1.62^{\mathrm{Ca}} \pm 0.27$ & $1.37^{\mathrm{Bb}} \pm 0.20$ & $1.27^{\mathrm{Bb}} \pm 0.27$ & $0.97^{\mathrm{Aa}} \pm 0.25$ \\
\hline pH & $5.78 \pm 0.44$ & $5.69 \pm 0.28$ & $5.75 \pm 0.42$ & $5.77 \pm 0.50$ & $5.62 \pm 0.23$ \\
\hline
\end{tabular}

Means with different letters (a,b; A,B) in lines differ significantly (LSD test: $\mathrm{P} \leq 0.05 ; \mathrm{P} \leq 0.01$ ).

Table 2

Mean \pm standard deviation of texture parameters, colour, and drip loss of beef muscles.

\begin{tabular}{llllll}
\hline \multicolumn{5}{c}{ Mean \pm standard deviation of texture parameters, colour, and drip loss of beef muscles. } \\
& $\begin{array}{l}\text { LTH } \\
(\mathrm{n}=20)\end{array}$ & $\begin{array}{l}\text { TRI } \\
(\mathrm{n}=20)\end{array}$ & $\begin{array}{l}\text { SEM } \\
(\mathrm{n}=20)\end{array}$ & $\begin{array}{l}\text { SET } \\
(\mathrm{n}=20)\end{array}$ & $\begin{array}{l}\text { PSM } \\
(\mathrm{n}=20)\end{array}$ \\
\hline Hardness & $24.63^{\mathrm{Aa}} \pm 7.62$ & $44.55^{\mathrm{Bb}} \pm 4.24$ & $20.86^{\mathrm{Aa}} \pm 6.13$ & $52.08^{\mathrm{Bb}} \pm 12.57$ & $21.92^{\mathrm{Aa}} \pm 5.82$ \\
\hline Shear energy & $0.099^{\mathrm{Aa}} \pm 0.031$ & $0.168^{\mathrm{Bb}} \pm 0.043$ & $0.091^{\mathrm{Aa}} \pm 0.025$ & $0.189^{\mathrm{Bb}} \pm 0.074$ & $0.106^{\mathrm{Aa}} \pm 0.034$ \\
\hline Tenderness & $11.90^{\mathrm{Aa}} \pm 2.88$ & $23.16^{\mathrm{Bb}} \pm 6.40$ & $10.71^{\mathrm{Aa}} \pm 2.78$ & $25.94^{\mathrm{Bb}} \pm 6.68$ & $11.70^{\mathrm{Aa}} \pm 2.76$ \\
\hline $\mathrm{L}^{*}$ value $(\%)$ & $36.84^{\mathrm{Aa}} \pm 3.58$ & $37.40^{\mathrm{Aa}} \pm 2.70$ & $35.90^{\mathrm{Aa}} \pm 4.59$ & $41.19^{\mathrm{Bb}} \pm 4.74$ & $36.25^{\mathrm{Aa}} \pm 2.81$ \\
\hline $\mathrm{a}^{*}$ value & $19.37^{\mathrm{Aa}} \pm 2.85$ & $23.11^{\mathrm{BCcd}} \pm 2.28$ & $20.83^{\mathrm{ABab}} \pm 3.99$ & $21.69^{\mathrm{ABCb}} \pm 4.08$ & $23.78^{\mathrm{Ca}} \pm 2.78$ \\
\hline $\mathrm{b}^{*}$ value & $8.53^{\mathrm{Aa}} \pm 2.17$ & $10.28^{\mathrm{ABbc}} \pm 1.61$ & $9.50^{\mathrm{ABac}} \pm 2.81$ & $11.44^{\mathrm{Bb}} \pm 3.18$ & $10.93^{\mathrm{Bbc}} \pm 1.97$ \\
\hline Drip loos $(\%)$ & $2.24 \pm 1.33$ & $1.95 \pm 0.64$ & $3.00 \pm 1.20$ & $3.04 \pm 1.13$ & $2.32 \pm 1.39$ \\
\hline
\end{tabular}

Means with different letters (a,b; A,B) in lines differ significantly (LSD test: $\mathrm{P} \leq 0.05 ; \mathrm{P} \leq 0.01$ ).

The LTH was characterised by the highest fat content $(2.17 \%, \mathrm{P} \leq 0.05)$, whereas the lowest content was reported for the PSM (1.09\%), though at a comparable level to the SEM $(1.34 \%, \mathrm{P}>0.05)$. The LTH, SEM, and SET contained the highest protein level $(22.5 \%)$ and the results differed statistically $(\mathrm{P}<0.01)$ from those obtained for the TRI $(21.9 \%)$ and PSM $(21.8 \%)$. With regard to the connective tissue content, the highest value was obtained in the TRI $(1.61 \%)$, but at a comparable level to the LTH. The lowest content was reported in the PSM $(0.97 \%)$.

Jeremiah et al. (12), Prieto et al. (28), and Chang et al. (4) had previously indicated a difference between the basic meat composition of various kinds of beef muscles. These researchers identified many factors, which may influence the results, such as the intensity of muscle work, a calorific value of the animal feed, methods and duration of aging, etc.

The instrumental measurement of texture parameters by shear force test with Warner-Bratzler attachment allowed for the determination of differences between various muscles in regard to hardness $(\mathrm{N})$ (maximum shear force), shear energy (J) (area below curve), and tenderness (N) (shear force at first peak on the curve) (Table 2). Values of hardness, shear energy, and tenderness were significantly lower for SEM, PSM, and LTH than in SET and TRI $(\mathrm{P} \leq 0.01)$. Lu et al. (19) suggested that the sequence of tenderness of raw beef muscles might be as follows: SET > SEM > LD $(m$. longissimus dorsi). Differences between the texture parameters of individual muscles may be a consequence of various factors: the proportion of isotropic (bright) to anisotropic fibers (dark), thickness perimysium (3), $\mathrm{pH}$ (20), structure and composition of connective tissue (29), intramuscular fat (IMF) (17), and sarcomere length (32).
The highest value of lightness was recorded for SET $\left(L^{*}=41.19 \%\right)$; the values of lightness of other muscles were significantly $(\mathrm{P} \leq 0.01)$ lower $\left(\mathrm{L}^{*} \approx 36 \%\right)$. The highest redness was recorded for PSM $\left(\mathrm{a}^{*}=23.78\right)$ and TRI $\left(\mathrm{a}^{*}=23.11\right)$, whereas the lowest was for LTH $\left(a^{*=19.37)} \quad(\mathrm{P} \leq 0.01)\right.$. Yellowness $\left(b^{*}=8.53\right)$ of LTH differed statistically $(\mathrm{P} \leq 0.01)$ from values recorded for this parameter for SEM and PSM $\left(b^{*}=11.44\right.$ and $b^{*}=10.93$, respectively). Page et al. (25) obtained 25.05 as a value of redness ( $\mathrm{a}^{*}$ ) for LTH and 10.94 as a value of yellowness $\left(b^{*}\right)$. Differences in colour of individual muscles can be caused by myoglobin content, connective tissue, as well as the colour of intramuscular fat $(11,21)$.

The values of drip loss ranged from 1.95 to 3.04. The difference between results might have been influenced by the protein and collagen content of meat. Furthermore, aging may affect water binding ability as well. Some scientists also claim that the increasing ability to bind water is related to the degradation of cytoskeletal proteins (15).

Correlation between basic meat compositions, pH value, and selected physical properties of bovine muscles. Correlation analysis can be used to estimate and predict many quality parameters of beef. The values of correlation coefficients are presented in Table 3. Low correlation was found between the intramuscular fat content and hardness $(\mathrm{N})$ $(-0.078 \leq r \leq 0.261)$, shear energy (J) $(-0.148 \leq r \leq 0.314)$, and tenderness $(\mathrm{N})(0.068 \leq \mathrm{r} \leq 0.312)$ in all muscles, with the exception of the SEM. A significantly high positive correlation was observed between fat content and hardness $\quad(\mathrm{r}=0.673)$, shear energy $\quad(\mathrm{r}=0.648)$, and tenderness $(\mathrm{r}=0.666)$ in the SET. Change of colour parameters $L^{*}, a^{*}, b^{*}$ were slightly dependent on changing intramuscular fat contents. 


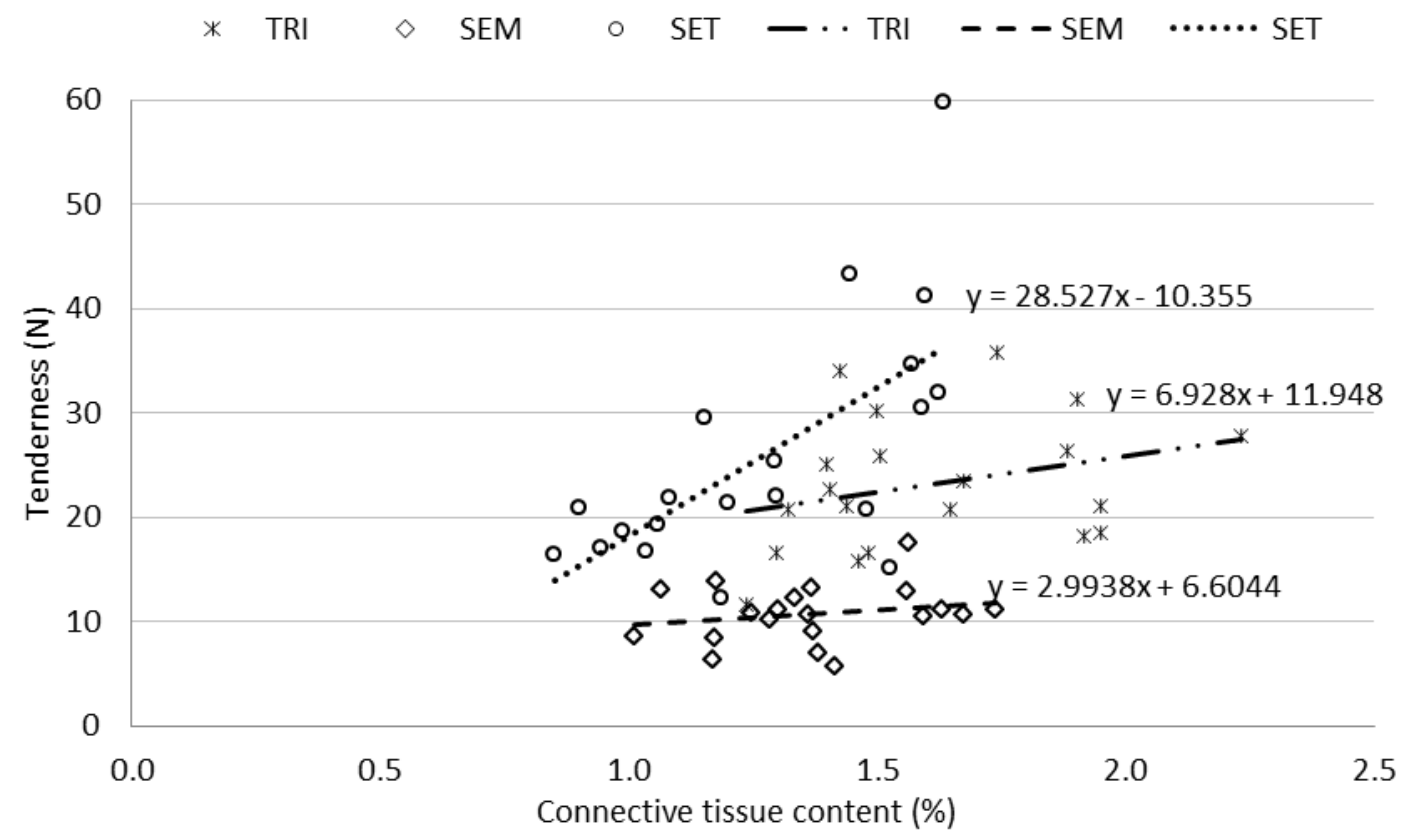

Fig. 1. Relationship between tenderness (N) and connective tissue content (\%) of various bovine muscles: TRI - M. triceps brachii; SEM - M. semimembranosus; SET - M. semitendinosus.

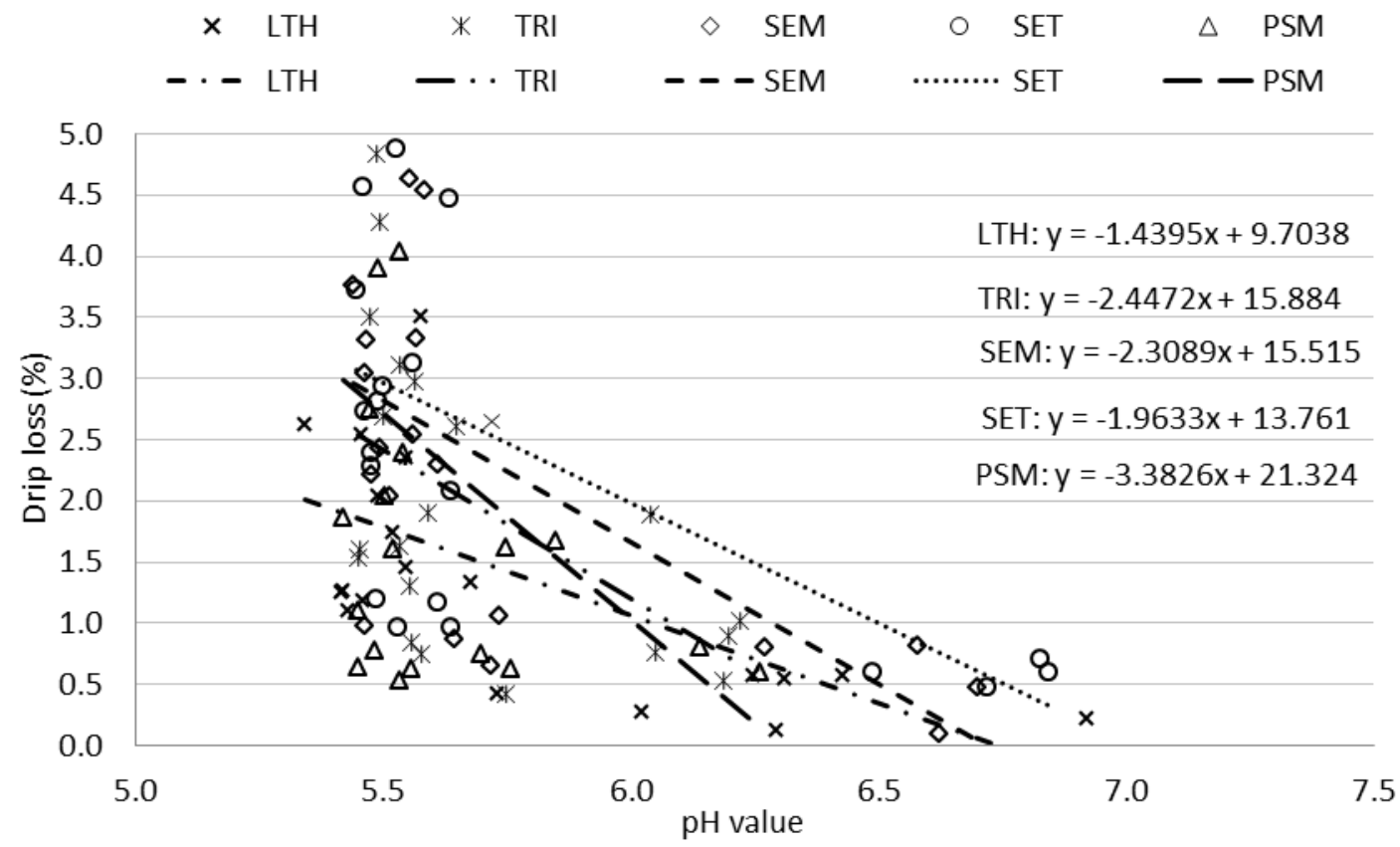

Fig. 2. Relationship between drip loss (\%) and $\mathrm{pH}$ value of various bovine muscles: LTH - M. longissimus thoracis et lumborum; TRI - M. triceps branchii; SEM - M. semimembranosus; SET - M. semitendinosus; PSM - M. psoas major.

Only in the case of the SEM, the correlation was moderate, but statistically significant $\left(\mathrm{r}_{\mathrm{L}^{*}}=0.514\right.$, $\mathrm{P} \leq 0.05 ; \quad \mathrm{r}_{\mathrm{a}^{*}}=0.444, \quad \mathrm{P} \leq 0.05 ; \quad \mathrm{r}_{\mathrm{b}^{*}}=0.573$, $\mathrm{P} \leq 0.01)$.Correlation coefficient between drip loss and the intramuscular fat content was positive and moderate for the TRI $(r=0.442)$, SEM $(r=0.465, P \leq 0.05)$, and high for the SET $(r=0.605, \mathrm{P} \leq 0.01)$.

No significant correlations were found between protein content and any other physical parameters except for lightness $\left(\mathrm{L}^{*}\right)$. A moderate negative correlation, statistically significant $(\mathrm{P} \leq 0.05)$, was noted for the PSM,
SET, and TRI. Connective tissue content positively correlated with texture parameters (hardness, shear energy, tenderness (Fig. 1)). However, a high correlation was found only for the SET ( $r_{\text {hardness }}=0.673, r_{\text {shear energy }}$ $\left.=0.605, \mathrm{r}_{\text {tenderness }}=0.653 ; \mathrm{P} \leq 0.01\right)$.

High positive correlation was recorded between connective tissue content and drip loss size for the TRI $(\mathrm{r}=0.635 ; \mathrm{P} \leq 0.01)$ and a moderate correlation for the SEM $(\mathrm{r}=0.556 ; \mathrm{P} \leq 0.05)$. 
Table 3

Correlation analysis between the basic meat composition, $\mathrm{pH}$, and physical characteristics of beef muscles

\begin{tabular}{|c|c|c|c|c|}
\hline & \multicolumn{3}{|c|}{ Content } & \multirow{2}{*}{$\mathrm{pH}$} \\
\hline & Fat & Protein & Connective tissue & \\
\hline \multicolumn{5}{|l|}{ LTH } \\
\hline Hardness (N) & -0.078 & 0.001 & 0.064 & 0.039 \\
\hline Shear energy (J) & -0.148 & 0.009 & 0.120 & 0.01 \\
\hline Tenderness $(\mathrm{N})$ & -0.083 & 0.260 & 0.117 & -0.139 \\
\hline Drip loss (\%) & 0.166 & 0.021 & 0.391 & $-0.501 *$ \\
\hline $\begin{array}{l}\mathrm{L}^{*} \text { value } \\
(\%)\end{array}$ & -0.163 & -0.120 & 0.127 & $-0.689 * * *$ \\
\hline a* value & 0.267 & -0.122 & $0.463 *$ & $-0.542 *$ \\
\hline $\mathrm{b}^{*}$ value & 0.273 & 0.018 & $0.453 *$ & $-0.719 * * *$ \\
\hline \multicolumn{5}{|l|}{ TRI } \\
\hline Hardness (N) & 0.023 & -0.106 & 0.372 & $-0.629 * *$ \\
\hline Shear energy $(\mathrm{J})$ & 0.092 & -0.087 & 0.379 & $-0.644 * *$ \\
\hline Tenderness $(\mathrm{N})$ & -0.079 & -0.283 & 0.297 & $-0.566^{* *}$ \\
\hline Drip loss (\%) & 0.442 & 0.016 & $0.635 * *$ & $-0.529 *$ \\
\hline $\mathrm{L}^{*}$ value $(\%)$ & 0.070 & $-0.485^{*}$ & 0.228 & -0.338 \\
\hline$a *$ value & 0.281 & -0.080 & $0.510^{*}$ & $-0.828 * * *$ \\
\hline$b^{*}$ value & 0.325 & 0.018 & 0.434 & $-0.912 * * *$ \\
\hline \multicolumn{5}{|l|}{ SEM } \\
\hline Hardness (N) & 0.235 & 0.158 & 0.326 & $-0.522 *$ \\
\hline Shear energy $(\mathrm{J})$ & 0.314 & 0.349 & 0.350 & $-0.625 * *$ \\
\hline Tenderness $(\mathrm{N})$ & 0.272 & 0.223 & 0.219 & $-0.554 *$ \\
\hline Drip loss (\%) & $0.465 *$ & 0.087 & $0.556^{*}$ & $-0.601 * *$ \\
\hline $\mathrm{L}^{*}$ value $(\%)$ & $0.514 *$ & -0.194 & 0.320 & $-0.756 * * *$ \\
\hline a* value & $0.444 *$ & 0.059 & $0.517 *$ & $-0.742 * * *$ \\
\hline $\mathrm{b}^{*}$ value & $0.573 * *$ & 0.168 & $0.542 *$ & $-0.837 * * *$ \\
\hline \multicolumn{5}{|l|}{ SET } \\
\hline Hardness (N) & $0.673 * *$ & 0.125 & $0.673 * *$ & -0.184 \\
\hline Shear energy (J) & $0.648 * *$ & 0.222 & $0.605 * *$ & -0.258 \\
\hline Tenderness $(\mathrm{N})$ & $0.666^{* *}$ & -0.013 & $0.653 * *$ & -0.188 \\
\hline Drip loss $(\%)$ & $0.605 * *$ & 0.118 & 0.333 & $-0.556^{*}$ \\
\hline $\mathrm{L}^{*}$ value $(\%)$ & 0.417 & $-0.518^{*}$ & -0.022 & $-0.831 * * *$ \\
\hline$a^{*}$ value & 0.282 & 0.096 & 0.133 & $-0.593 * *$ \\
\hline $\mathrm{b}^{*}$ value & 0.361 & 0.378 & 0.128 & $-0.779 * * *$ \\
\hline \multicolumn{5}{|l|}{ PSM } \\
\hline Hardness $(\mathrm{N})$ & 0.261 & -0.422 & $-0.491 *$ & -0.432 \\
\hline Shear energy $(\mathrm{J})$ & 0.117 & -0.227 & 0.383 & -0.370 \\
\hline Tenderness $(\mathrm{N})$ & 0.261 & -0.343 & $-0.462 *$ & $-0.495^{*}$ \\
\hline Drip loss $(\%)$ & -0.082 & -0.052 & -0.021 & -0.282 \\
\hline $\mathrm{L}^{*}$ value $(\%)$ & -0.084 & $-0.553^{*}$ & -0.201 & $-0.745^{* * *}$ \\
\hline$a^{*}$ value & -0.072 & -0.417 & $-0.502 *$ & $-0.811 * * *$ \\
\hline $\mathrm{b}^{*}$ value & -0.043 & -0.388 & $-0.523 *$ & $-0.820 * * *$ \\
\hline
\end{tabular}

* - $\mathrm{P} \leq 0.05 ; * *-\mathrm{P} \leq 0.01 ; * * *-\mathrm{P} \leq 0.001$ 
Positive, moderate correlation was observed for the LTH, TRI, and SEM between connective tissue content and coordinates $\mathrm{a}^{*}$ and $\mathrm{b}^{*}\left(0.463 \leq \mathrm{r}_{\mathrm{a}^{*}} \leq 0.517\right.$; $\mathrm{P} \leq 0.05$ and $\left.0.434 \leq \mathrm{r}_{\mathrm{b}^{*}} \leq 0.542 ; \mathrm{P} \leq 0.05\right)$.For the TRI, $\mathrm{SEM}$, and PSM, the relation between muscle $\mathrm{pH}$ value and texture parameters obtained in the shear test was negative, moderate, or high. Statistically significant $(\mathrm{P} \leq 0.01)$ correlations were obtained for the TRI $\left(r_{\text {hardness }}=-0.629, \quad r_{\text {shear }}\right.$ energy. $\left.=-0.644, \quad r_{\text {tenderness. }}=-0.566\right)$. Strong correlations between $\mathrm{pH}$ value and hardness $(\mathrm{r}=$ $0.522 ; \mathrm{P} \leq 0.05), \mathrm{pH}$ value and shear energy $(\mathrm{r}=-0.625$; $\mathrm{P} \leq 0.01$ ) were recorded for SEM as well.

Braghieri et al. (2) indicated a linear and positive correlation between the $\mathrm{pH}$ value measured 1 , 24 , and $48 \mathrm{~h}$ after slaughter and the tenderness of beef meat (M. longissimus dorsi) after 2 and $7 \mathrm{~d}$ of aging process (tenderness evaluated by a sensory panel). However, no significant correlation was found between $\mathrm{pH}$ and tenderness determined by instruments. Furthermore, the research showed that the initial value of $\mathrm{pH}$ ( $1 \mathrm{~h}$ after slaughter) and the final value ( $48 \mathrm{~h}$ after slaughter) were both good indicators of meat tenderness. The same authors implied that meat with a higher final $\mathrm{pH}$ value was initially more tender than meat with a normal $\mathrm{pH}$ value due to rapid meat tenderisation. Nevertheless, these differences decreased when prolonging the aging process. Moreover, the correlation between $\mathrm{pH}$ value and tenderness was less significant in relation to values obtained during $2^{\text {nd }} d$ of aging.

Negative moderate correlation was reported between drip loss size and $\mathrm{pH}$ values $(-0.601 \leq \mathrm{r} \leq-0.501)$, with the exception of the PSM ( $\mathrm{r}=-0.282)$ (Fig. 2).

Based on the analysis of $\mathrm{pH}$ values of muscles and parameters $L^{*}, a^{*}, b^{*}$, significant Pearson correlation coefficients were negative. Lightness $\left(\mathrm{L}^{*}\right)$ strongly correlated with the $\mathrm{pH}$ value of the SET $(\mathrm{r}=$ $0.831 ; \mathrm{P} \leq 0.001)$ and considerably correlated in case of the SEM and PSM ( $\mathrm{r}=-0.756$ and $\mathrm{r}=-0.745$, respectively; $\mathrm{P} \leq 0.001$ ).

Very strong relationship was recorded between $\mathrm{pH}$ values and redness $\left(\mathrm{a}^{*}\right)$ for the PSM $(\mathrm{r}=-0.811$; $\mathrm{P} \leq 0.001)$ and the TRI $(\mathrm{r}=-0.828 ; \mathrm{P} \leq 0.001)$, and a strong correlation was found in case of the SEM ( $\mathrm{r}=-0.742$; $\mathrm{P} \leq 0.001)$. Parameters for yellowness $\left(\mathrm{b}^{*}\right)$ indicated a very high correlation with $\mathrm{pH}$ value $(-0.912 \leq \mathrm{r} \leq-0.719$; $\mathrm{P} \leq 0.001)$ for all examined muscles. Page et al. (25) also found a negative correlation between $\mathrm{pH}$ value and $\mathrm{L}^{*}$ $(\mathrm{r}=-0.40), \mathrm{a}^{*}(\mathrm{r}=-0.58), \mathrm{b}^{*}(\mathrm{r}=-0.56)$ due to increasing $\mathrm{pH}$ values of meat. Values of colour parameters tended to decrease. The strong negative correlation between $\mathrm{pH}$ values and muscle colour might be explained by the colour of muscle tissue being conditioned by reflectance light of free water and a degree of oxidation of myoglobin (1).

Proteins have a higher ability to bind water in muscles with higher $\mathrm{pH}$ values. This leads to a lower level of free water and results in limiting free space between swelling muscle fibres. Meat with higher $\mathrm{pH}$ value is darker because there is less free water, which reflects light. In muscles with a higher $\mathrm{pH}$, enzymes using oxygen are more active, which leads to lower oxygenation of myoglobin and a darker colour (25).
In conclusion, raw beef meat characteristics depend on many factors such as: genotype, age, sex, type of feeding, transport conditions, slaughter, duration, and temperature of aging process. These variables influence quality of beef (colour, tenderness, flavour, juiciness). $\mathrm{pH}$ values, connective tissue, and intramuscular fat content are indicators used to determine the colour, tenderness, hardness and level of drip loss. Basic meat composition (water, protein, fat, and connective tissue content) depends on the muscle type, its location, and muscle work intensity during animal's life. Muscles, which work less (e.g. LTH) contain more fat and less connective tissue in comparison with TRI and SEM. The drip loss correlates strongly negatively with the $\mathrm{pH}$ value of beef. Drip loss correlates moderately positively with connective tissue content in beef muscles. Hardness and tenderness correlate strongly positively with fat content in SEM. Colour parameters are most dependent on $\mathrm{pH}$ values and in to a lesser degree on the content of connective tissue.

Acknowlegments: The study was realised within the Project No. WND-POIG.01.03.01-00-204/09 Optimising of Beef Production in Poland According to "from Fork to Farm" Strategy co-financed by the European Regional Development Fund under the Innovative Economy Operational Programme 20072013.

\section{References}

1. Abril M., Campo M.M., Onenc A., Sanudo C., Alberti P., Negueruela A.I.: Beef colour evolution as a function of ultimate $\mathrm{pH}$. Meat Sci 2001, 58, 69-78.

2. Braghieri A., Carlucci A., Girolami A., Napolitano F.: Tenderness, $\mathrm{pH}$ and acceptability of meat from Podolian and Limousine $\mathrm{x}$ Podolian young bulls. J Food Qual 2008, 31, 490-502.

3. Brooks J.C., Savell J.W.: Perimysium thickness as an indicator of beef tenderness. Meat Sci 2004, 67, 329334.

4. Chang H.J., Xu X.L., Li C.B., Huang M., Liu D.Y., Zhou G.H.: A comparison of heat-induced changes of intramuscular connective tissue and collagen of beef semitendinosus muscle during water bath and microwave heating. J Food Process Eng 2010, 34, 1-18.

5. Destefanis G., Brugiapaglia A., Barge M.T., Dal Molin E.: Relationship between beef consumer tenderness perception and Warner-Bratzler shear force. Meat Sci 2008, 78, 153-156.

6. Gašperlin L., Žlender B., Abram V.: Colour of normal and high $\mathrm{pH}$ beef heated to different temperatures as related to oxygenation. Meat Sci 2000, 54, 391-398.

7. Hannula T., Puolanne E.: The effect of cooling rate on beef tenderness: The significance of $\mathrm{pH}$ at $7^{\circ} \mathrm{C}$. Meat Sci 2004, 67, 403-408.

8. Hernández B., Lizaso G., Horcada A., Beriain M.J., Purroy A.: Meat colour of fighting bulls. Arch Latinoam Prod Anim 2006, 14, 90-94.

9. Hwang I.H., Thompson J.M.: The interaction between $\mathrm{pH}$ and temperature decline early postmortem on the calpain system and objective tenderness in electrically 
stimulated beef longissimus dorsi muscle. Meat Sci 2001, 58, 167-174.

10. Iwanowska A., Iwańska E., Grześ B., Mikołajczak B., Pospiech E., Rosochacki S., Juszczuk-Kubiak E., Łyczyński A.: Changes in proteins and tenderness of meat from young bulls of four breeds at three ages over 10 days of cold storage. Anim Sci Pap Rep 2010, 28, 13 25.

11. Jakobsen M., Bertelson G.: Colour stability and lipid oxidation of fresh beef. Development of a response surface model for predicting the effects of temperature, storage time, and modified atmosphere composition. Meat Sci 2000, 54, 49-57.

12. Jeremiah L.E., Dugan M.E.R., Aalhus J.L., Gibson L.L.: Assessment of palatability attributes of the major beef muscles. Meat Sci 2003, 65, 985-992.

13. Jeremiah L.E., Phillips D.M.: Evaluation of a probe for predicting beef tenderness. Meat Sci 2000, 55, 493-502.

14. Koohmaraie M., Geesink G.H.: Contribution of postmortem muscle biochemistry to the delivery of consistent meat quality with particular focus on calpain system. Meat Sci 2006, 74, 34-43.

15. Kristensen L., Purslow P.: The effect of aging on the water-holding capacity of pork: role of cytoskeletal proteins. Meat Sci 2001, 58, 17-23.

16. Lawrie R.A., Ledward D.A.: Lawrie's meat science. Cambridge, England: Woodhead Publishing Ltd. 2006.

17. Li Ch., Zhou G., Xu X., Zhang J., Xu S., Ji Y.: Effects of marbling on meat quality characteristics and intramuscular connective tissue of beef longissimus muscle. Asian Aust J Anim Sci 2006, 19, 1799-1808.

18. Li Ch., Zhou G., Xu X.: Changes of meat quality characteristics and intramuscular connective tissue of beef semitendinosus muscle during postmortem aging for Chinese Yellow bulls. Int J Food Sci Tech 2008, 43, 838-845.

19. Lu R., Chen Y.-R., Solomon M.B., Berry B.W.: Tensile properties and Warner-Bratzler tenderness measurement of raw and cooked beef. Transact ASAE 1998, 41, 14311439.

20. Maltin C., Balcerzak D., Tilley R., Delday M.: Determinants of meat quality: tenderness. P Nutr Soc 2003, 62, 337-347.

21. Mancini R.A., Hunt M.C.: Current research in meat color. Meat Sci 2005, 71, 100-121.
22. Mlček J., Šustová K., Simeonovová J.: Application of FT NIR spectroscopy in the determination of basic chemical composition of pork and beef. Czech J Anim Sci 2006, 51, 361-368.

23. Monsón F., Sanudo C., Sierra I.: Influence of cattle breed and ageing time on textural meat quality. Meat Sci 2004, 68, 595-602.

24. Nishimura T.: The role of intramuscular connective tissue in meat texture. Anim Sci J 2010, 81, 21-27.

25. Page J.K., Wulf D.M., Schwotzer T.R.: A survey of beef muscle color and pH. J Anim Sci 2001, 79, 678-687.

26. PN-ISO 2917:2001/Ap1:2002: Mięso i przetwory mięsne. Pomiar $\mathrm{pH}$. Metoda odwoławcza.

27. Prevolnik M., Čandek-Potokar M., Škorjanc D., Velikonja-Bolta Š., Škrlep M., Žnidaršič T., Babnik D.: Predicting intramuscular fat content in pork and beef by near infrared spectroscopy. J Near Infrared Spectrosc 2005, 13, 77-85.

28. Prieto N., Ross D.W., Navajas E.A., Nute G.R., Richardson R.I., Hyslop J.J., Simm G., Roehe R.: Online application of visible and near infrared reflectance spectroscopy to predict chemical-physical and sensory characteristics of beef quality. Meat Sci 2009, 83, 96103.

29. Purslow P.P.: Intramuscular connective tissue and its role in meat quality. Meat Sci 2005, 70, 435-447.

30. Saito K., Ahhmed A., Takeda H., Kawahara S., Irie M., Muguruma M.: Effects of a humidity-stabilizing sheet on the color and $\mathrm{K}$ value of beef stored at cold temperatures. Meat Sci 2007, 75, 265-272.

31. Schönfeldt H.C., Strydom P.E.: Effect of age and cut on tenderness of South African beef. Meat Sci 2011, 87, 206-218.

32. Stolowski G.D., Baird B.E., Miller R.K., Savell J.W., Sams A.R., Taylor J.F., Sanders J.O., Smith S.B.: Factors influencing the variation in tenderness of seven major beef muscles from three Angus and Brahman breed crosses. Meat Sci 2006, 73, 475-483.

33. Torrescano G., Sánchez-Escalante A., Giménez B., Roncalés P., Beltrán J.A.: Shear values of raw samples of 14 bovine muscles and their relations to muscle collagen characteristics. Meat Sci 2003, 64, 85-91.

34. Warris P.D.: Meat Science. An Introductory text. School of Veterinary Science University of Bristol, Bristol UK, Cabi Publishing 2010, pp. 194-205. 